\title{
The Role of Cytokines in Sleep Regulation
}

\author{
James M. Krueger ${ }^{\star}$ \\ Sleep and Performance Research Center, College of Veterinary Medicine, Washington State \\ University, Pullman, WA 99164-6520, USA
}

\begin{abstract}
Interleukin-1 beta (IL1) and tumor necrosis factor alpha (TNF) promote non-rapid eye movement sleep under physiological and inflammatory conditions. Additional cytokines are also likely involved but evidence is insufficient to conclude that they are sleep regulatory substances. Many of the symptoms induced by sleep loss, e.g. sleepiness, fatigue, poor cognition, enhanced sensitivity to pain, can be elicited by injection of exogenous IL1 or TNF. We propose that ATP, released during neurotransmission, acting via purine $\mathrm{P} 2$ receptors on glia releases IL1 and TNF. This mechanism may provide the means by which the brain keeps track of prior usage history. IL1 and TNF in turn act on neurons to change their intrinsic properties and thereby change input-output properties (i.e. state shift) of the local network involved. Direct evidence indicates that cortical columns oscillate between states, one of which shares properties with organism sleep. We conclude that sleep is a local use-dependent process influenced by cytokines and their effector molecules such as nitric oxide, prostaglandins and adenosine.
\end{abstract}

\section{Keywords}

Local sleep; interleukin; TNF; neurotrophin; adenosine; purine P2 receptors

\section{INTRODUCTION}

Sleep is important because it is integral to most issues in neurobiology and neuropathology. Further, sleep and sleep pathologies are of direct importance to the quality of our life. Although our understanding of sleep remains limited much has been accomplished over the past 20 years especially within the context of cytokine regulation of sleep and related physiological and pathophysiological processes. The evidence that cytokines are involved in physiological sleep regulation and their relationships to other sleep regulatory substances (SRSs) is the focus of this review [reviewed 1,2,3]. Many laboratories have developed what is now overwhelming evidence linking sleep deprivation-enhanced inter-leukin-1 beta (IL1), and the related cytokine tumor necrosis factor alpha (TNF), to symptoms associated with sleep deprivation, such as sensitivity to kindling [4] and pain stimuli [5,6,7], cognitive [8,9,10], memory [11,12,13], and performance impairments [11], depression [14,15], sleepiness [2,16,17], and fatigue [14,18, 19]. Further, chronic sleep loss is associated with pathologies such as metabolic syndrome [20,21,22], chronic inflammation [23,24], and cardiovascular disease [reviewed 25]. All of these sleep deprivation-associated symptoms can be induced by injection of exogenous IL1 and/or TNF [reviewed 1,2], or in some cases blocked if these cytokines are inhibited [21,26, 27]. An inhibitor of IL1, the IL1-receptor antagonist (IL1RA) is a naturally-occurring substance

*Address correspondence to this author at the Sleep and Performance Research Center, College of Veterinary Medicine, Washington State University, Pullman, WA 99164-6520, USA; Tel: (509) 335-8212; Fax: (509) 335-1676; E-mail: E-mail: krueger@ vetmed.wsu.edu. 
whose levels are altered by sleep loss [23] and inhibits sleep [28]. Similarly, the TNF soluble receptor (sTNFR) is altered by sleep loss and inhibits sleep in animal models [2]. Both the IL1RA and the sTNFR are approved for clinical use. The IL1RA reduces fatigue in rheumatoid arthritis patients [19] and improves pancreatic beta cell function [21]. The sTNRF reduces fatigue [29] and sleepiness in sleep apnea patients [30]. These and other findings have transformed our views of sleep pathologies such as sleep apnea and chronic restricted sleep; they are now considered inflammatory disorders. Further, the cytokine sleep literature has contributed much to our understanding of sleep regulation and what exactly it is that sleeps.

\section{HUMORAL REGULATION OF SLEEP}

Many of the variables that affect sleep have been linked to hormonal and humoral mechanisms (Fig. 1). These mechanisms are often linked to each other in biochemical cascades and feedback loops (Fig. 2) and link sleep to multiple other physiological and mental processes (Fig. 1). They operate to affect sleep over very different time scales ranging from the life span of the individual to milliseconds (Fig. 1). Although cytokines are involved in the regulation of many of the variables listed in Fig. (1), the sheer number of substances and physiological processes, and the substantially different time scales suggest the involvement of a distributed network of semiautonomous regulatory events at both the biochemical and cellular levels. Such distributed regulatory networks are common in biological and engineered systems. The regulatory output is an emergent property of the entire system. Experimentally, it is possible to amplify one or more of the individual mechanisms to affect sleep, e.g. injection of a SRS or stimulation of a sleep regulatory circuit. Similarly, sleep disorders occurring during pathologies likely result from the disproportionate stimulation of one or more of the humoral/hormonal mechanisms shown in Fig. (1).

We have known for almost 100 years that mammalian cerebrospinal fluid contains sleep promoting substances that accumulate during wakefulness [2,31]. Indeed, these findings have led to the identification of many of these substances (Fig. 2). However, it is not possible to isolate sleep as the independent variable because most, if not all, physiological parameters change with sleep. As a consequence, investigators have developed lists of criteria to be met before a substance is considered a sleep regulatory substance [32-35]. Criteria common to these lists are: a) The substance if injected should enhance sleep. b) If inhibited, sleep should be reduced. c) The level of the substance should vary in brain with sleep propensity. d) The substance should act on sleep regulatory circuits. e) The substance should be altered in pathological states associated with enhanced sleepiness. All of these criteria have been met by IL1, TNF, growth hormone releasing hormone (GHRH), adenosine, and prostaglandin $\mathrm{D}_{2}$ for non-rapid eye movement sleep (NREMS) regulation. For rapid eye movement sleep (REMS) regulation, prolactin, $\mathrm{NO}$, and vasoactive intestinal polypeptide also meet these requirements [reviewed 2]. The evidence dealing with cytokines is expanded upon here.

Cytokines such as IL1 have long evolutionary histories; they date to jawless vertebrates 500 million years ago and related cytokines date to invertebrates occurring at least 850 million years ago [36]. Cytokines are well-known for their roles in host defense but may have initially evolved for other purposes [36]. IL1 was first implicated in sleep regulation about 25 years ago by the finding that it has the capacity to enhance non rapid eye movement sleep (NREMS) [37]. In subsequent years, a plethora of additional evidence suggests that IL1 and other cytokines such as TNF, epidermal growth factor (EGF), and brain-derived neurotrophic factor (BDNF) are SRSs (Table 1) [reviewed 2,3,36]. There is evidence that these mechanisms and related effector substances are dependent on metabolism and are shared by fruit flies and mammals, e.g. EGF [38,39], nuclear factor kappa B (NFkB) [40-44] and adenosine [45]. 
Central or systemic injection of IL1 or TNF enhances duration of NREMS and electroencephalogram (EEG) delta (1/2-4Hz) power (an index of sleep intensity) and/or sleepiness in every species thus far tested including, mice, rats, rabbits, sheep, cats, monkeys, and humans [reviewed 1-3,36]. Injection of exogenous low doses of IL1 or TNF enhances NREMS. Conditions that enhance endogenous production of IL1 or TNF, e.g., excessive food intake [46] or infectious disease [47], promote NREMS [2,3]. Conversely, inhibition of endogenous IL1 or TNF, using antibodies or endogenous inhibitors such as their soluble receptors or the IL1RA, inhibits spontaneous sleep [1,2,3,36]. These inhibitors of IL1 and TNF also inhibit sleep rebound after sleep deprivation. Brain levels of IL1 mRNA and IL1 and plasma levels of IL1 vary with the sleep-wake cycle with highest levels correlating with high sleep propensity. Brain levels of TNF and TNF mRNA also vary with sleep propensity in a similar fashion. Both IL1 mRNA and TNF mRNA increase in the brain during sleep deprivation. The IL1 type I receptor and the TNF55kD receptor are responsible for IL1- and TNF-enhanced NREMS since mice lacking these receptors do not respond to IL1 or TNF and have less spontaneous sleep respectively [48,49]. Microinjection of TNF [50,51] into the anterior hypothalamus enhances NREMS. IL1 enhances the firing rate of hypothalamic sleepactive neurons while it inhibits wake-active neurons [52]. Some hypothalamic neurons receptive for GHRH are also receptive for IL1 [53]. These data suggest that this NREMS regulatory network is responsive to IL1 and TNF. Both IL1 and TNF affect, or are affected by, several neurotransmitter systems involved in the activation networks. For example, injection of IL1 into the locus coeruleus [54], or the dorsal raphe promotes NREMS [55]. Collectively, these and other data [reviewed 1,2,3,] indicate that IL1 and TNF are involved in physiological NREMS regulation as well as changes in sleep associated with pathologies.

Both IL1 and TNF have been linked to a variety of clinical conditions involving sleep disorders [reviewed 1-3,36]. For instance, TNF is elevated in patients with chronic fatigue syndrome, chronic insomniac patients, postdialysis fatigue preeclampsia, alcoholism, myocardial infarction, influenza virus infections, rheumatoid arthritis, and sleep apnea. Further, the TNF polymorphic variant, G-308A, is associated with metabolic syndrome and sleep apnea.

Several additional cytokines have the capacity to promote sleep, most notably since they were discovered by neuroscientists rather than by immunologists, are the neurotrophins.

Neurotrophins 1 (NGF), 2 (BDNF), 3 and 4 as well as glia-derived neurotrophic factor all can promote sleep (Table 1). For example, NGF induces NREMS [57], if injected

intracerebroventricularly (ICV), and REMS [58], if injected into the pontine reticular formation. Giant reticular cells and neurons in the mesencephalic trigeminal nucleus are immunoreactive for the 75 and trk A NGF receptors. These neurons may modify NGF-induced REMS [59]. Further, if NGF receptive basal forebrain cholinergic neurons are removed using an immunotoxin conjugated to an anti-p75 NGF receptor, there is a transient loss of NREMS and a more permanent loss of REMS [60]. After sleep loss, NGF1-A (also called Erg-1 and Zif 268) up regulates in the locus coeruleus [61]. NGF1-A is a transcription factor induced by NGF via trk A receptors. NGF-IR also increases in the somatosensory cortex after sleep loss [62]. Notably, after ICV injection, NGF induces a reduction in EEG delta power during NREMS [57]. Many other somnogenic cytokines, e.g., IL1 and TNF, enhance EEG delta power although some can either enhance or inhibit EEG delta power depending on conditions, e.g. TNF [2] and BDNF [63,64]. Collectively, such data suggest that NGF and other neurotrophins play a role in sleep.

Other cytokines that may also be involved in the regulation of sleep include; IL2, IL6, IL8, IL15, IL18, EGF, acidic fibroblast growth factor, colony stimulating factor, and interferons (Table 1; [reviewed 2,3]). In contrast, other cytokines inhibit NREMS including the IL1RA, IL4, IL10, IL13, insulin-like growth factor, transforming growth factor beta and the soluble IL1 and TNF receptors [reviewed 2,3]. Although collectively these data strongly suggest that 
the brain cytokine network participates in sleep regulation, it is premature to conclude that any of these cytokines, other than IL1 and TNF, is an SRS.

The regulation of cytokines in the brain is complex and not very well understood. Nevertheless, some cytokine-associated substances, such as the IL1RA and the TNF and IL1 soluble receptors seem to act as endogenous antagonists, and indeed these substances inhibit spontaneous sleep [reviewed 1,2,3,36]. Anti-somnogenic cytokines act, in part, by inhibiting production of prosomnogenic cytokines (Fig. 2). For example, IL10 inhibits IL1 and TNF production and also inhibits production of IL1 receptor types I and II. Further, exogenous IL10 inhibits production or release of other somnogenic substances implicated in sleep regulation, including NGF and NO and it increases the production of sleep-inhibitory substances such as corticotropin releasing hormone and the IL1RA. IL4 inhibits IL1 and TNF production and it also increases the production of the IL1RA and release of the soluble TNF receptor. Furthermore, IL4 inhibits production or release of other substances implicated in sleep regulation, e.g., NO. Both IL4 and IL10 inhibit sleep (e.g., Fig. 2) and are in brain.

IL1 downstream mechanisms indicate its involvement in many other substances implicated in sleep regulation (Fig. 2). IL1 promotes NFkB activation and in turn IL1 production is enhanced by NFkB activation [reviewed 2]. NFkB is a transcription factor usually acting as an enhancer element for a wide array of genes, including other cytokines, such as TNF, NGF and EGF, and other SRSs such as the adenosine A1 receptor, the gluR1 component of AMPA receptors, cyclooxygenase, and NO synthase (Fig. 2). There may be some degree of specificity for NFkB activation to sleep. Sleep loss enhances hypothalamic and cortical NFkB activation [40,65]. Adenosine also elicits NFkB nuclear translocation in basal forebrain via the adenosine A1 receptor [66]. Finally, an inhibitor of NFkB inhibits duration of NREMS [41]. Thus via the actions of IL1 on NFkB and the NFkB-enhanced enzymes and receptors, shorter lived molecules known to be involved in sleep regulation are recruited into the sleep regulatory biochemical cascade including adenosine, NO, and prostaglandins. That these mechanisms are also very likely involved in the regulation of local cerebral blood flow highlights the relationships between cellular metabolism, sleep and blood flow.

Upstream events involved in IL1 synthesis and release suggest a close relationship to cell activity and metabolism in the brain. There is an extensive literature relating neuronal activity to neurotrophin expression [reviewed 67] and these relationships form in part the basis of the neurotrophin hypothesis [68]. Other cytokines such as IL1 are less well studied in this regard although it is known that excessive endogenous stimulation, as occurs during kindling [4] or during sleep deprivation [69], enhances IL1 expression. Activity in neurons is translated into pre- and post-synaptic events that manifest in both the short run and long run. Thus ATP is coreleased with neurotransmitters (Fig. 2) [reviewed 70,71]; in turn ectonucleotidases hydrolyze some of that ATP to adenosine. Adenosine acts on neurons via the adenosine A1 receptor to hyperpolarize cells via $\mathrm{K}^{+}$channels [45]. ATP also acts via $\mathrm{P} 2 \mathrm{X} 7$ receptors on microglia to induce the release of IL1 and TNF [72-75]. For example, macrophages obtained from mice lacking the P2X7 receptor fail to elaborate IL1 if challenged with endotoxin [74]. ATP-released cytokines in turn act on cells bearing their receptors to activate NFkB. A second method used to demonstrate activity-dependence of cytokines uses the whisker stimulation-somatosensory cortex rat model. After 2 hours of whisker twitching, in the cortical column that receives afferent input from the whisker, TNF-immunoreactivity (IR) in neurons is enhanced while in adjacent cortical columns enhanced TNF-IR is not observed [76]. It is not known if the enhanced neuronal TNF expression results from TNF uptake from the microglia-released TNF or if it is synthesized in the neuron of its expression.

IL1 and TNF may also provide a bridge between the circadian rhythm and the sleep homeostat (Fig. 2). There are daily rhythms in brain cytokines including IL1 and TNF [reviewed 2]. 
Removal of the type I IL1 receptor results in sleep deficits that are limited to the night hours [48] while removal of the TNF $55 \mathrm{kD}$ receptor disrupts sleep during the transition between nighttime and daytime [49]. Finally, IL1 and TNF inhibit expression of some clock genes via interfering with CLOCK-BMAL1-induced activation of E-box regulatory elements [77] (Fig. 2).

\section{ORGANIZATION OF SLEEP}

If a subject survives a brain lesion, whether experimental or pathological, for a few days or more, it sleeps. There apparently are no reported cases of subjects with complete lack of sleep including those with fatal familial insomnia [78]. This is an important meta-finding for sleep research because it indicates that sleep is a property of any surviving group of neurons. From comparative studies, it appears that many species of birds and marine mammals exhibit unihemispheric sleep $[79,80,81]$. A defining characteristic of NREMS, EEG delta waves, has a local cortical origin [82]. Further, isolated cortical islands that retain their blood flow, wax and wane through periods of high amplitude delta waves [83]. Clinical evidence also indicates the brain can be awake and asleep simultaneously, e.g. parasomnias such as sleep walking [84]. Collectively, such data indicate sleep has characteristics of a local process.

IL1 [85], TNF [86] and other SRSs including GHRH [87], and BDNF [64] have the capacity to act locally within the cortex to alter a sleep phenotype, EEG delta power. EEG delta power is indicative of NREMS intensity; e.g. it is enhanced during the deep sleep that follows sleep deprivation [35,88]. Unilateral application of IL1 or TNF (Fig. 3) to the surface of the cortex enhances EEG delta power during NREMS, but not during REMS or waking, on the ipsilateral side but not on the contralateral side suggesting that sleep is more intense on the side receiving IL1 $[85,86]$. These unilateral changes in EEG delta power are associated with changes in Fos and IL1-IR in the corresponding cortical areas and reticular thalamus [89,90] suggesting the involvement of the biochemical sleep regulatory cascade (Fig. 2) and known thalamo-cortical sleep regulatory circuitry [82]. These data coupled with what is known about use-dependent production of IL1, TNF, NGF, and BDNF strongly support the idea that sleep is targeted to active circuits and is initiated at a local network level. Further, local application of TNF to cortical columns is associated with cortical column state changes [3]. Such changes suggest that sleep is a fundamental property of neuronal networks.

The idea that sleep is a local process is directly supported by the finding that cortical columns oscillate between sleep-like and wake-like states [91]. Further sleep intensity, a sleep phenotype determined from EEG delta power, is dependent upon prior use and is targeted and localized to areas disproportionately used during prior wakefulness. EEG delta power is enhanced in the left somatosensory cortex compared to the right during NREMS after prolonged right hand stimulation prior to sleep onset [92]. Other evidence is consistent with the idea that sleep is a regional property of brain dependent upon prior activity. In mice, rats, chickens, pigeons, humans and cats, if a localized area is disproportionately stimulated during waking, EEG delta power in that area is enhanced during subsequent NREMS [93-102]. There are also several findings showing that cerebral blood flow during sleep is enhanced in those areas disproportionately stimulated during prior waking [103,104]. Finally, the developmental plasticity literature [105-107] and the learning literature demonstrating replay of neuronal electrical patterns associated with waking learning tasks [108], indicate changes in the EEG during sleep are targeted to areas activated during prior waking.

Previously we and many others had proposed that waking activity results in the accumulation of SRSs that provide a humoral signal that enhances sleepiness and sleep $[34,35,88]$. However, that literature for the past 100 years has not posited what it was about wakefulness that caused the enhanced SRS production. We propose that it is neurotransmission-released ATP [3]. There 
is a large rich literature demonstrating co-release of ATP with neurotransmitters including sites within the cortex and other areas of brain [reviewed 70,71]. Much of this literature focused on ATP co-released with glutamate although the current consensus is that ATP is released with most, if not all, neurotransmitters. There is an independent large literature demonstrating ATPenhanced release of cytokines from immunocytes via purine P2 receptors [for IL1 reviewed 109,110]. The immunocyte literature has been extended to the brain; ATP induces IL1, TNF and BDNF release from glia via $\mathrm{P} 2$ receptors [reviewed 72-75,111]. For example, both IL1 and TNF are released from microglia upon activation of the P2X7 receptor. IL1, TNF, NGF, and BDNF are all putative gliotransmitters. Since these cytokines are also putative SRSs it seems logical to posit that, via ATP release that P2R receptors and their subsequent induction of cytokine release, the brain keeps track of prior sleep/wake activity. It also seems likely that sleep would affect P2R expression and that cytokines may provide a feedback signal to alter $\mathrm{P} 2 \mathrm{R}$ receptors. The neurotransmission-ATP-P2 receptor mechanism also provides a way to target sleep to active circuits.

Mechanistically our hypothesis is summarized as follows (Fig. 4) [3]. Neuronal activity is associated with synaptic co-release of ATP with the neurotransmitter. The consequent increase in extracellular ATP thus provides a transitory measure of prior local neuronal activity. The ATP is detected by nearby glia P2Rs causing the release of sleep regulatory cytokines such as IL1 and this provides for the translation of prior neuronal activity into local levels of SRSs. These substances in turn, by a slow process (gene transcription/translation), alter electrical properties of nearby neurons by altering their own production and that of receptor populations, such as AMPA and adenosine receptors. The SRSs also, by a fast process (diffusion for short distances), directly interact with their receptors on neurons and alter electrical properties. Further, ATP is hydrolyzed by ectonucleotidases releasing extracellular adenosine that in turn acts on adenosine receptors again altering electrical potentials on the nearby neurons. These events are happening locally and the collective electrical changes result in a shift in inputoutput relationships within the local neuronal assemblies that originally exhibited the increase in activity, i.e. a state shift. In a mathematical model, the local state of neuronal assemblies synchronize, also called phase locking, with each other because they are loosely connected to each other via neurons and humorally [56]. Well characterized sleep regulatory circuits and associated activation networks likely ensure the synchronization of neuronal assembly state for niche-adaptation purposes.

There are many good reviews dealing with mammalian sleep regulatory circuitry [e.g. 82, $112-115]$. A fundamental premise of the sleep regulatory circuitry literature is that such circuits impose sleep on the brain; hence sleep is viewed as being initiated by these circuits. The sleep regulatory circuit paradigm is mechanistically silent on many well-known sleep phenomena, e.g. performance detriments associated with prolonged wakefulness, sleep homeostasis, many sleep parasomnias such as sleep-walking, reoccurrence and reorganization of sleep after lesions. In contrast, our theory [116,117 and others [118-120] posit that sleep is initiated locally within neuronal assemblies depending upon past use ${ }^{1}$ and addresses all these issues. If we consider input to a cortical column (neuronal assembly) during waking to induce an environmentally adaptive output then during the sleep-like state the new output in response to the same input would likely not be relevant to the environmentally-driven input. If that output manifested in motor or cognitive real-time outputs, behavior would not be coordinated with real-time environmental inputs and this would lead to dysfunction. Thus, within the context of our theory, it is easy to envision, as well as being experimentally demonstrated [91] how some cortical columns may be awake while simultaneously other cortical columns are asleep within the same brain. As sleep loss progresses we propose that the number of cortical columns in the

${ }^{1}$ Both the local and circuit theories invoke von Economo's idea that sleep is actively regulated, not a passive process. Further, they are not mutually exclusive. 
sleep-like state would increase and indeed Rector et al. [91] showed that the probability of any column being in the sleep-like state increases the longer it has been in the wake-like state. Assuming performance depend upon the coordinated actions of multiple columns in the wake state, if some of those columns are in the sleep-like state, performance whether cognitive functioning or muscle co-ordination would likely suffer.

\section{CONCLUSION}

The biochemical mechanisms responsible for sleep regulation are very complex. Explaining physiological sleep and sleep disturbances occurring during pathology is possible within the context of the brain cytokine network, although incomplete.

\section{ACKNOWLEDGMENTS}

This work was supported by NS25378, NS31453 and HD36520.

\section{REFERENCES}

1. Kapsimalis F, Richardson G, Opp MR, Kryger M. Cytokines and normal sleep. Curr Opin Pulm Med 2005;11:481-484. [PubMed: 16217172]

2. Obál F Jr, Krueger JM. Biochemical regulation of non-rapid-eye-movement sleep. Frontiers Biosci 2003;8:520-550.

3. Krueger JM, Rector DM, Churchill L. Sleep and cytokines. Sleep Med Clin 2007;2:161-169. [PubMed: 19098992]

4. Yi PL, Tsai CH, Lin JG, Lee CC, Chang FC. Kindling stimuli delivered at different times in the sleepwake cycle. Sleep 2004;27:203-212. [PubMed: 15124712]

5. Kundermann B, Hemmeter-Spernal J, Huber MT, Krieg JC, Lautenbacher S. Effects of total sleep deprivation in major depression: Overnight improvement of mood is accompanied by increased pain sensitivity and augmented pain complaints. Psychosom Med 2008;70:92-101. [PubMed: 18158380]

6. Honore P, Donnelly-Roberts D, Namovic MT, Hsieh G, Zhu CZ, Mikusa JP, et al. A-740003 [N-(1$\{[($ Cyanoimino)(5-quinolinyl-amino) methyl $]$ amin $\}$-2,2-dimethylpropyl)-2-(3,4-dimethoxyphe-nyl) acetamide], a novel and selective $\mathrm{P}_{2} \mathrm{X}_{7}$ receptor antagonist, dose-dependently reduces neuropathic pain in the rat. J Pharmacol Exp Therap 2006;319:1376-1385. [PubMed: 16982702]

7. Kawasaki Y, Zhang L, Cheng J-K, Ji R-R. Cytokine mechanisms of central sensitization: Distinct and overlapping role of interleukin-1 $\beta$, Interleukin- 6 and tumor necrosis factor- $\alpha$ in regulating synaptic and neuronal activity in the superficial spinal cord. J Neurosci 2008;28:5189-5194. [PubMed: 18480275]

8. Trompet S, de Craen AJ, Slagboom P, Shepherd J, Blauw GJ, Murphy MB, et al. PROSPER Group. Genetic variation in the interleukin-1 beta-converting enzyme associates with cognitive function. The PROSPER study. Brain 2008;131:1069-1077. [PubMed: 18304957]

9. Baune BT, Ponath G, Rothermundt M, Riess O, Funke H, Berger K. Association between genetic variants of IL-1beta, IL-6 and TNF-alpha cytokines and cognitive performance in the elderly general population of the MEMO-study. Psychoneuroendocrinology 2008;33:68-76. [PubMed: 17988804]

10. Gambino F, Pavlowsky A, Béglé A, Dupont JL, Bahi N, Courjaret R, et al. IL1-receptor accessory protein-like 1 (IL1RAPL1), a protein involved in cognitive functions, regulates $\mathrm{N}$-type Ca2+-channel and neurite elongation. Proc Natl Acad Sci USA 2007;104:3-9068. [PubMed: 17190800]

11. Banks S, Dinges DF. Behavioral and physiological consequences of sleep restriction. J Clin Sleep Med 2007;3:519-528. [PubMed: 17803017]

12. Pickering M, O'Connor JJ. Pro-inflammatory cytokines and their effects in the dentate gyrus. Prog Brain Res 2007;163:339-354. [PubMed: 17765728]

13. Dantzer R. Cytokin-induced sickness behavior: A neuroimmune response to activation of innate immunity. Eur J Pharmacol 2004;500:399-411. [PubMed: 15464048]

14. Anisman H, Marali Z. Cytokines, stress and depressive illness: Brain-immune interactions. Ann Med 2003;35:2-11. [PubMed: 12693607] 
15. Vollmer-Conna U, Fazou C, Cameron B, Li H, Brennan C, Luck L, et al. Production of proinflammatory cytokines correlates with the symptoms of acute sickness behavior in humans. Psychol Med 2004;34:128-1297.

16. Moldofsky H. Sleep, neuroimmune and neuroendocrine functions in fibromyalgia and chronic fatigue syndrome. Adv Neuroimmunol 1995;5:39-56. [PubMed: 7795892]

17. Tringall G, Dello Russo C, Preziosi P, Navarra P. Interleukin-1 in the central nervous system: From physiology to pathology. Therapie 2000;55:171-175. [PubMed: 10860021]

18. Carmichael MD, Davis JM, Murphy EA, Brown AS, Carson JA, Mayer EP, et al. Role of brain IL-1beta on fatigue after exercise-induced muscle damage. Am J Physiol Regul Integr Comp Physiol 2006;291:R1344-R1348. [PubMed: 16778069]

19. Omdal R, Gunnarsson R. The effect of interleukin-1 blockade on fatigue in rheumatoid arthritis - a pilot study. Rheumatol Int 2005;25:481-484. [PubMed: 15071755]

20. Jager J, Grémeaux T, Cormont M, LeMarchand-Brustel Y, Tanti JF. Interleukin-1beta-induced insulin resistance in adipocytes through down-regulation of insulin receptor substrate-1 expression. Endocrinology 2007;148:241-251. [PubMed: 17038556]

21. Larsen CM, Faulenbach M, Vaag A, Velund A, Ehses JA, Seifert B, et al. Interleukin-1-receptor antagonist in type 2 diabetes mellitus. N Engl J Med 2007;356:1517-1526. [PubMed: 17429083]

22. Hristova M, Aloe L. Metabolic syndrome-neurotrophic hypothesis. Med Hypotheses 2006;66:545549. [PubMed: 16298496]

23. Frey DJ, Fleshner M, Wright KP Jr. The effects of 40 hours of total sleep deprivation on inflammatory markers in healthy young adults. Brain Behav Immun 2007;21:1050-1057. [PubMed: 17524614]

24. Hu J, Chen Z, Gorczynski CP, Gorczynski LY, Kai Y, Lee L, et al. Sleep-deprived mice show altered cytokine production manifest by perturbations in serum IL-1ra, TNFa, and IL-6 levels. Brain Behav Immun 2003;17:498-504. [PubMed: 14583241]

25. Yndestad A, Damås JK, Øie E, Ueland T, Gullestad L, Aukrust P. Role of inflammation in the progression of heart failure. Curr Cardiol Rep 2007;9:236-241. [PubMed: 17470337]

26. Depino AM, Alonso M, Ferrari C, del Rey A, Anthony D, Besedovsky H, et al. Learning modulation by endogenous hippocampal IL-1: Blockade of endogenous IL-1 facilitates memory formation. Hippocampus 2004;14:526-535. [PubMed: 15224987]

27. Opp MR, Krueger JM. Interleukin 1 receptor antagonist blocks interleukin 1-induced sleep and fever. Am J Physiol 1991;260:R453-R457. [PubMed: 1825458]

28. Takahashi S, Kapás L, Fang J, Wang Y, Seyer JM, Krueger JM. An interleukin-1 receptor fragment inhibits spontaneous sleep and muramyl dipeptide-induced sleep in rabbits. Am J Physiol 1996;271:R101-R108. [PubMed: 8760209]

29. Franklin CM. Clinical experience with soluble TNF p75 receptor in rheumatoid arthritis. Semin Arthritis Rheum 1999;29:172-181. [PubMed: 10622681]

30. Vgontzas AN, Zoumakis E, Lin HM, Bixler EO, Trakada G, Chrousos GP. Marked decrease in sleepiness in patients with sleep apnea by etanercept, a tumor necrosis factor-alpha antagonist. J Clin Endocrinol Metab 2004;89:4409-4413. [PubMed: 15356039]

31. Pappenheimer JR, Miller TB, Goodrich CA. Sleep-promoting effects of cerebrospinal fluid from sleep-deprived goats. Proc Natl Acad Sci USA 1967;58:513-517. [PubMed: 5233454]

32. Krueger, JM.; Obál, F, Jr. Sleep Factors. Sleep and Breathing. New York: Marcel Dekker, Inc.; 1994. p. 79-112.

33. Jouvet M. Neuromediateurs et facteurs hypnogenes. Rev Neurol (Paris) 1984;140:389-400. [PubMed: 6147008]

34. Inoué, S. Biology of sleep substances. Boca Raton, Florida: CRC Press, Inc.; 1989.

35. Borbély AA, Tobler I. Endogenous sleep-promoting substances and sleep regulation. Physiol Rev 1989;69:605-670. [PubMed: 2564687]

36. Opp MR. Cytokines and Sleep. Sleep Med Rev 2005;9:355-364. [PubMed: 16102986]

37. Krueger JM, Walter J, Dinarello CA, Wolff SM, Chedid L. Sleep-promoting effects of endogenous pyrogen (interleukin-1). Am J Physiol 1984;246:R994-R999. [PubMed: 6611091]

38. Kushikata T, Fang J, Chen Z, Wang Y, Krueger JM. Epidermal growth factor enhances spontaneous sleep in rabbits. Am J Physiol 1998;275:R509-R514. [PubMed: 9688687] 
39. Foltenyi K, Greenspan RJ, Newport JW. Activation of EGFR and ERK by rhomboid signaling regulates the consolidation and maintenance of sleep in Drosophila. Nature Neurosci 2007;10:11601167. [PubMed: 17694052]

40. Chen Z, Gardi J, Kushikata T, Fang J, Krueger JM. Nuclear factor-kappaB-like activity increases in murine cerebral cortex after sleep deprivation. Am J Physiol 1999;276:R1812-R1818. [PubMed: 10362764]

41. Kubota T, Kushikata T, Fang J, Krueger JM. Nuclear factor-kappaB inhibitor peptide inhibits spontaneous and interleukin-1 beta-induced sleep. Am J Physiol Regul Integr Comp Physiol 2000;279:R404-R413. [PubMed: 10938226]

42. Yamauchi M, Tamaki S, Tomoda K, Yoshikawa M, Fukuoka A, Makinodan K, et al. Evidence for activation of nuclear factor kappaB in obstructive sleep apnea. Sleep Breath 2006;10:189-193. [PubMed: 17013605]

43. Ramesh V, Thatte HS, McCarley RW, Basheer R. Adenosine and sleep deprivation promote NFkappaB nuclear translocation in cholinergic basal forebrain. J Neurochem 2007;100:1351-1363. [PubMed: 17316404]

44. Williams JA, Sathyanarayanan S, Hendricks JC, Sehgal A. Interaction between sleep and the immune response in Drosophila: A role for the NFkappaB relish. Sleep 2007;30:389-400. [PubMed: 17520783]

45. Basheer R, Strecker RE, Thakkar MM, McCarley RW. Adenosine and sleep-wake regulation. Prog Neurobiol 2004;73:379-396. [PubMed: 15313333]

46. Hansen MK, Taishi P, Chen Z, Krueger JM. Cafeteria-feeding induces interleukin-1 beta mRNA expression in rat liver and brain. Am J Physiol 1998;43:R1734-R1739. [PubMed: 9841485]

47. Toth LA, Krueger JM. Alteration of sleep in rabbits by Staphylococcus aureus infection. Infect Immun 1988;56:1785-1791. [PubMed: 3384477]

48. Fang J, Wang Y, Krueger JM. The effects of interleukin-1 beta on sleep are mediated by the type I receptor. Am J Physiol 1998;274:R655-R660. [PubMed: 9530230]

49. Fang J, Wang Y, Krueger JM. Mice lacking the TNF $55 \mathrm{kDa}$ receptor fail to sleep more after TNF alpha treatment. J Neurosci 1997;17:5949-5955. [PubMed: 9221791]

50. Terao A, Matsumura H, Yoneda H, Saito M. Enhancement of slow-wave sleep by tumor necrosis factor-alpha is mediated by cyclooxygenase-2 in rats. Neuroreport 1998;9:3791-3796. [PubMed: 9875706]

51. Kubota T, Li N, Guan Z, Brown RA, Krueger JM. Intrapreoptic microinjection of TNF-alpha enhances non-REMS in rats. Brain Res 2002;932:37-44. [PubMed: 11911859]

52. Alam MN, McGinty D, Bashir T, Kumar S, Imeri L, Opp MR, et al. Interleukin-1beta modulates state-dependent discharge activity of preoptic area and basal forebrain neurons: Role in sleep regulation. Eur J Neurosci 2004;20:207-216. [PubMed: 15245493]

53. De A, Churchill L, Obal F Jr, Simasko SM, Krueger JM. GHRH and IL1beta increase cytoplasmic $\mathrm{Ca}^{2+}$ levels in cultured hypothalamic GABAergic neurons. Brain Res 2002;949:209-212. [PubMed: 12213318]

54. De Sarro G, Gareri P, Sinopoli VA, David E, Rotiroti D. Comparative, behavioural and electrocortical effects of tumor necrosis factor-alpha and interleukin-1 microinjected into the locus coeruleus of rat. Life Sci 1997;60:555-564. [PubMed: 9042390]

55. Manfridi A, Brambilla D, Bianchi S, Mariotti M, Opp MR, Imeri L. Interleukin-1beta enhances nonrapid eye movement sleep when microinjected into the dorsal raphe nucleus and inhibits serotonergic neurons in vitro. Eur J Neurosci 2003;18:1041-1049. [PubMed: 12956704]

56. Roy S, Krueger JM, Rector DM, Wan Y. A network model for activity-dependent sleep regulation. J Theor Biol 2008;253:462-468. [PubMed: 18511082]

57. Takahashi S, Krueger JM. Nerve growth factor enhances sleep in rabbits. Neurosci Lett 1999;264:149-152. [PubMed: 10320036]

58. Yamuy J, Morales FR, Chase MH. Induction of rapid eye movement sleep by microinjection of nerve growth factor into the pontine reticular formation of the cat. Neuroscience 1995;66:9-13. [PubMed: 7637879]

59. Yamuy J, Sampogna S, Chase MH. Neurotrophin-receptor immunoreactive neurons in mesopontine regions involved in the control of behavioral states. Brain Res 2000;866:1-14. [PubMed: 10825475] 
60. Kapas L, Obal F Jr, Book AA, Schweitzer JB, Wiley RG, Krueger JM. The effects of immunolesions of nerve growth factor-receptive neurons by 192 IgG-saporin on sleep. Brain Res 1996;712:53-59. [PubMed: 8705307]

61. Tononi G, Pompeiano M, Cirelli C. The locus coeruleus and immediate-early genes in spontaneous and forced wakefulness. Brain Res Bull 1994;35:589-596. [PubMed: 7859116]

62. Brandt J, Churchill L, Guan Z, Fang J, Chen L, Krueger JM. Sleep deprivation, but not a whisker trim, increases nerve growth factor within barrel cortical neurons. Brain Res 2001;898:105-112. [PubMed: 11292453]

63. Kushikata T, Fang J, Krueger JM. Brain-derived neurotrophic factor enhances spontaneous sleep in rats and rabbits. Am J Physiol 1999;276:R1334-R1338. [PubMed: 10233024]

64. Faraguna U, Vyazovskiy VV, Nelson AB, Tononi G, Cirelli C. A causal role for brain-derived neurotrophic factor in the homeostatic regulation of sleep. J Neurosci 2008;28:4088-4095. [PubMed: 18400908]

65. Brandt JA, Churchill L, Rehman A, Ellis G, Mémet S, Israël A, et al. Sleep deprivation increases the activation of nuclear factor kappa B in lateral hypothalamic cells. Brain Res 2004;1004:91-97. [PubMed: 15033423]

66. Basheer R, Rainnie DG, Porkka-Heiskanen T, Ramesh V, McCarley RW. Adenosine, prolonged wakefulness, and A1-activiated NF-kappaB DNA binding in the basal forebrain of the rat. Neuroscience 2001;104:731-739. [PubMed: 11440805]

67. Dechant G, Neumann H. Neurotrophins. Adv Exp Med Biol 2002;513:303-334. [PubMed: 12575826]

68. Schinder AF, Poo M. The neurotrophin hypothesis for synaptic plasticity. Trends Neurosci 2000;23:639-645. [PubMed: 11137155]

69. Taishi P, Chen Z, Obal F Jr, Hansen MK, Zhang J, Fang J, et al. Sleep-associated changes in interleukin-1 beta mRNA in the brain. J Interferon Cytokine Res 1998;18:793-798. [PubMed: 9781819]

70. Burnstock G. Physology and pathophysiology of purinergic neurotransmission. Physiol Rev 2007;87:659-797. [PubMed: 17429044]

71. Farber K, Kettenmann H. Purinergic signaling and microglia. Pflugers Arch 2006;452:615-621. [PubMed: 16791619]

72. Hide I, Tanaka M, Inoue A, Nakajima K, Kohsaka S, Inoue K, Nakata Y. Extracellular ATP triggers tumor necrosis factor-alpha release from rat microglia. J Neurochem 2000;75:965-972. [PubMed: 10936177]

73. Suzuki T, Hide I, Ido K, Kohsaka S, Inoue K, Nakata Y. Production and release of neuroprotective tumor necrosis factor by P2X7 receptor-activated microglia. J Neurosci 2004;24:1-7. [PubMed: 14715932]

74. Solle M, Labsi J, Perragaux DG, Stam E, Petrushova N, Killer BH, et al. Altered cytokine production in mice lacking P2X(7) receptors. J Biol Chem 2001;276:125-132. [PubMed: 11016935]

75. Bianco F, Pravettoni E, Colombi A, Schenk U, Moller T, Matteoli M, et al. Astrocyte-derived ATP induces vesicle shedding and IL-1 beta release from microglia. J Immunol 2005;174:7268-7677. [PubMed: 15905573]

76. Fix C, Churchill L, Hall S, Krueger JM. The number of tumor necrosis factor $\alpha$-immunoreactive cells increases in layer IV of the barrel field in response to whisker deflection in rats. Sleep 2006;29:A11.

77. Cavadini G, Petrzilka S, Kohler P, Jud C, Tobler I, Birchier T, et al. TNF- $\alpha$ suppresses the expression of clock genes by interfering with E-box-mediated transcription. PNAS 2007;104:12843-12848. [PubMed: 17646651]

78. Montagna P. Fatal familial insomnia: A model disease in sleep physiopathology. Sleep Med Rev 2005;9:339-353. [PubMed: 16109494]

79. Rattenborg NC, Amlaner CJ, Lima SL. Unilateral eye closure and interhemispheric EEG asymmetry during sleep in the pigion (Columba livia). Brain Behav Evol 2001;58:323-332. [PubMed: 12016351]

80. Lyamin OI, Lapierre JL, Kosenko PO, Mukhametov LM, Siegel JM. Electroencephalogram asymmetry and spectral power during sleep in the northern fur seal. J Sleep Res 2008;17:154-165. [PubMed: 18482104] 
81. Lyamin OI, Mukhametov LM, Siegel JM, Nazarenko EA, Polyakova IG, Shpak OV. Unihemispheric slow wave sleep and the state of the eyes in a white whale. Behav Brain Res 2002;129:125-129. [PubMed: 11809503]

82. Steriade M. The corticothalamic system in sleep. Front Biosci 2003;8:d878-d899. [PubMed: 12700074]

83. Kristiansen K, Courtois G. Rhythmic electrical activity from isolated cerebral cortex. Electroencephalogr Clin Neurophysiol 1949;1:265-272. [PubMed: 18135418]

84. Mahowald MW, Schenck CH. Insights from studying human sleep disorders. Nature 2005;437:12791285. [PubMed: 16251953]

85. Yasuda T, Yoshida H, Garcia-Garcia F, Kay D, Krueger JM. Interleukin-1beta has a role in cerebral cortical state-dependent electro-encephalographic slow-wave activity. Sleep 2005;28:177-184. [PubMed: 16171241]

86. Yoshida H, Peterfi Z, Garcia-Garcia F, Kirkpatric R, Yasuda T, Krueger JM. State-specific asymmetries in EEG slow wave activity induced by local application of TNFalpha. Brain Res 2004;1009:129-136. [PubMed: 15120590]

87. Szentirmai E, Yasuda T, Taishi P, Wang M, Churchill L, Bohnet S, et al. Growth hormone-releasing hormone: Cerebral cortical sleep-related EEG actions and expression. Am J Physiol Regul Integr Comp Physiol 2007;293:R922-R930. [PubMed: 17537840]

88. Pappenheimer JR, Koski G, Fencl V, Karnovsky ML, Krueger J. Extraction of sleep-promoting factor S from cerebrospinal fluid and from brain of sleep-deprived animals. J Neurophysiol 1975;38:12991211. [PubMed: 1221075]

89. Yasuda K, Churchill L, Yasuda T, Blindheim K, Falter M, Krueger JM. Unilateral cortical application of interleukin-1beta (IL1beta) induces asymmetry in fos, IL1beta and nerve growth factor immunoreactivity: Implications for sleep regulation. Brain Res 2007;1131:44-59. [PubMed: 17184753]

90. Churchill L, Yasuda K, Yasuda T, Blindheim KA, Falter M, Garcia-Garcia F, et al. Unilateral cortical application of tumor necrosis factor alpha induces asymmetry in Fos- and interleukin-1 betaimmunoreactive cells within the corticothalamic projection. Brain Res 2005;1055:15-24. [PubMed: 16098952]

91. Rector DM, Topchiy IA, Carter KM, Rojas MJ. Local functional state differences between rat cortical columns. Brain Res 2005;1047:45-55. [PubMed: 15882842]

92. Kattler H, Dijk DJ, Borbely AA. Effect of unilateral somatosensory stimulation prior to sleep on the sleep EEG in humans. J Sleep Res 1994;3:159-164. [PubMed: 10607121]

93. Miyamoto H, Katagiri H, Hensch T. Experience-dependent slow-wave sleep development. Nat Neurosci 2003;6:553-554. [PubMed: 12754515]

94. Iwasaki N, Karashima A, Tamakawa Y, Katayama N, Nakao M. Sleep EEG dynamics in rat barrel cortex associated with sensory deprivation. Neuroreport 2004;15:2681-2684. [PubMed: 15570178]

95. Vyazovskiy VV, Tobler I. Handedness leads to interhemispheric EEG asymmetry during sleep in the rat. Neurophysiol 2008;99:969-975.

96. Vyazovskiy VV, Welker E, Fritschy JM, Tobler I. Regional pattern of metabolic activation is reflected in the sleep EEG after sleep deprivation combined with unilateral whisker stimulation in mice. Eur J Neurosci 2004;20:1363-1370. [PubMed: 15341608]

97. Vyazovskiy V, Borbely AA, Tobler I. Unilateral vibrissae stimulation during waking induces interhemispheric EEG asymmetry during subsequent sleep in the rat. J Sleep Res 2000;9:367-371. [PubMed: 11123523]

98. Cottone LA, Adamo D, Squires NK. The effect of unilateral soma-tosensory stimulation on hemispheric asymmetries during slow wave sleep. Sleep 2004;27:63-68. [PubMed: 14998239]

99. Ferrara M, De Gennaro L, Curcio G, Cristiani R, Bertini M. Inter-hemispheric asymmetry of human sleep EEG in response to selective slow-wave sleep deprivation. Behav Neurosci 2002;116:976-981. [PubMed: 12492296]

100. Huber R, Ghilardi MF, Massimini M, Ferrarelli F, Riedner BA, Peterson MJ, et al. Arm immobilization causes cortical plastic changes and locally decreases sleep slow wave activity. Nat Neurosci 2006;9:1169-1176. [PubMed: 16936722] 
101. Huber R, Ghilardi MF, Massimini M, Tononi G. Local sleep and learning. Nature 2004;430:27-28. [PubMed: 15229587]

102. Yasuda T, Yasuda K, Brown RA, Krueger JM. State-dependent effects of light-dark cycle on somatosensory and visual cortex EEG in rats. Am J Physiol Regul Integr Comp Physiol 2005;289:R1083-R1089. [PubMed: 16183627]

103. Maquet P. The role of sleep in learning and memory. Science 2001;294:1048-1052. [PubMed: 11691982]

104. Drummond SP, Brown GG. The effects of total sleep deprivation on cerebral responses to cognitive performance. Neuropsycho-pharmacology 2001;25:S68-S73.

105. Mascetti GG, Rugger M, Vallortigara G, Bobbo D. Monocular-unihemispheric sleep and visual discrimination learning in the domestic chick. Exp Brain Res 2007;176:70-84. [PubMed: 16874518]

106. Marks GA, Shaffery JP, Oksenberg A, Speciale SG, Roffwarg HP. A functional role for REM sleep in brain maturation. Behav Brain Res 1995;69:1-11. [PubMed: 7546299]

107. Frank MG, Issa NP, Stryker MP. Sleep enhances plasticity in the developing visual cortex. Neuron 2001;30:275-287. [PubMed: 11343661]

108. Ji D, Wilson MA. Coordinated memory replay in the visual cortex and hippocampus during sleep. Nat Neurosci 2007;10:100-107. [PubMed: 17173043]

109. Gabel CA. P2 purinergic receptor modulation of cytokine production. Purinergic Signal 2007;3:2738. [PubMed: 18404416]

110. Ferrari D, Pizzirani C, Adinolfi E, Lemoli R, Curti A, Idzko M, et al. The P2X7 receptor: A key player in IL-1 processing and release. J Immunol 2006;176:3877-3883. [PubMed: 16547218]

111. Verderio C, Bianco F, Blanchard MP, Bergami M, Canossa M, Scarfone E, et al. Cross talk between vestibular neurons and Schwann cells mediates BDNF release and neuronal regeneration. Brain Cell Biol 2006;35:187-201. [PubMed: 17957483]

112. Saper CB, Scammell TE, Lu J. Hypothalamic regulation of sleep and circadian rhythms. Nature 2005;473:1257-1263. [PubMed: 16251950]

113. Jones B. Arousal systems. Front Biosci 2003;8:s438-s451. [PubMed: 12700104]

114. McGinty D, Szymusiak R. Hypothalamic regulation of sleep and arousal. Front Biosci 2003;8:d1074-d1083.

115. Datta S, Maclean RR. Neurobiological mechanisms for the regulation of mammalian sleep-wake behavior: Reinterpretation of historical evidence and inclusion of contemporary cellular and molecular evidence. Neurosci Biobehav Rev 2007;31:775-824. [PubMed: 17445891]

116. Krueger JM, Obál F. A neuronal group theory of sleep function. J Sleep Res 1993;2:63-69. [PubMed: 10607073]

117. Krueger JM, Obal F Jr. Sleep function. Front Biosci 2003;8:511-519.

118. Kavanau JL. Sleep and dynamic stabilization of neural circuitry: A review and synthesis. Behav Brain Res 1994;63:111-126. [PubMed: 7999294]

119. Tononi G, Cirelli C. Sleep function and synaptic homeostasis. Sleep Med Rev 2006;10:49-62. [PubMed: 16376591]

120. Benington JH, Heller HC. Restoration of brain energy metabolism as the function of sleep. Prog Neurobiol 1995;45:347-360. [PubMed: 7624482] 


\begin{tabular}{|c|c|c|}
\hline Time Line of Regulation & Variable Affecting Sleep & $\begin{array}{l}\text { Hormonal and } \\
\text { Humoral Substances } \\
\text { Involved }\end{array}$ \\
\hline Years-Days- & 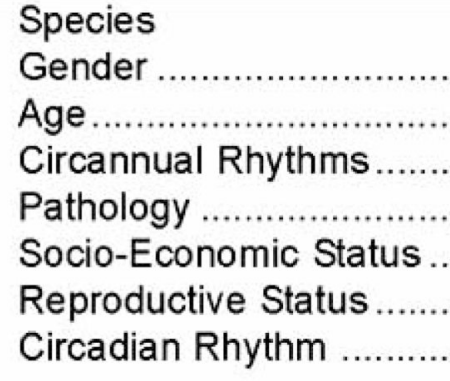 & $\begin{array}{l}. \text { Reproduction Hormones } \\
\text { Somatotropic Axis } \\
\text { Melatonin } \\
\text { Cytokines/Hormones } \\
\text { Stress Hormones } \\
\text { Reproductive Hormones, Prolactin } \\
\text { Clock Genes }\end{array}$ \\
\hline Days-Hours- & $\begin{array}{l}\text { Body Temperature ........... } \\
\text { Stress ............................ } \\
\text { Diet.......................... } \\
\text { Sleep Loss }\end{array}$ & $\begin{array}{l}\text { Prostaglandins, Cytokines } \\
\text { Glucocorticoids, CRH, Prolactin } \\
\text { Insulin, Mineralocorticoids } \\
\text { Cytokines, Adenosine, GHRH, PGD } \\
\text { Oleamide, VIP }\end{array}$ \\
\hline Hours-Minutes- & 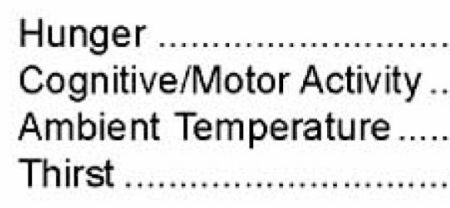 & $\begin{array}{l}\text { Ghrelin, CCK, NPY, Leptin, Orexin } \\
\text { Neurotrophins/Cytokines } \\
\text { TNF } \\
\text { Angiotensin, renin, aldosterone }\end{array}$ \\
\hline Minutes-Seconds $\longrightarrow$ & Sensory Withdrawal & \\
\hline Seconds-mseconds & $\begin{array}{l}\text { Afferent input } \\
\text { Excitatory stimuli ........ }\end{array}$ & $\begin{array}{l}\text { GABA, NO, Adenosine, ATP } \\
\text { Noradrenalin, acetylcholine histamine } \\
\text { Serotonin, glutamate }\end{array}$ \\
\hline
\end{tabular}

Fig. (1).

Many biological variables are associated with sleep patterns. The interveining hormonal and humoral substances acting to affect sleep are known in many cases; such substances act over different time lines to alter expressions of sleep phenotypes. Abbreviations: $\mathrm{CRH}$, corticotropin releasing hormone; GHRH, growth hormone releasing hormone; $\mathrm{PGD}_{2}$, prostaglandin $\mathrm{D}_{2}$; VIP, vasoactive intestinal polypeptide; TNF, tumor necrosis factor alpha; CCK, cholecystokinin; NPY, neuro-peptide Y; GABA, gamma amino butyric acid; NO, nitric oxide. 


\section{The Sleep Homeostat}

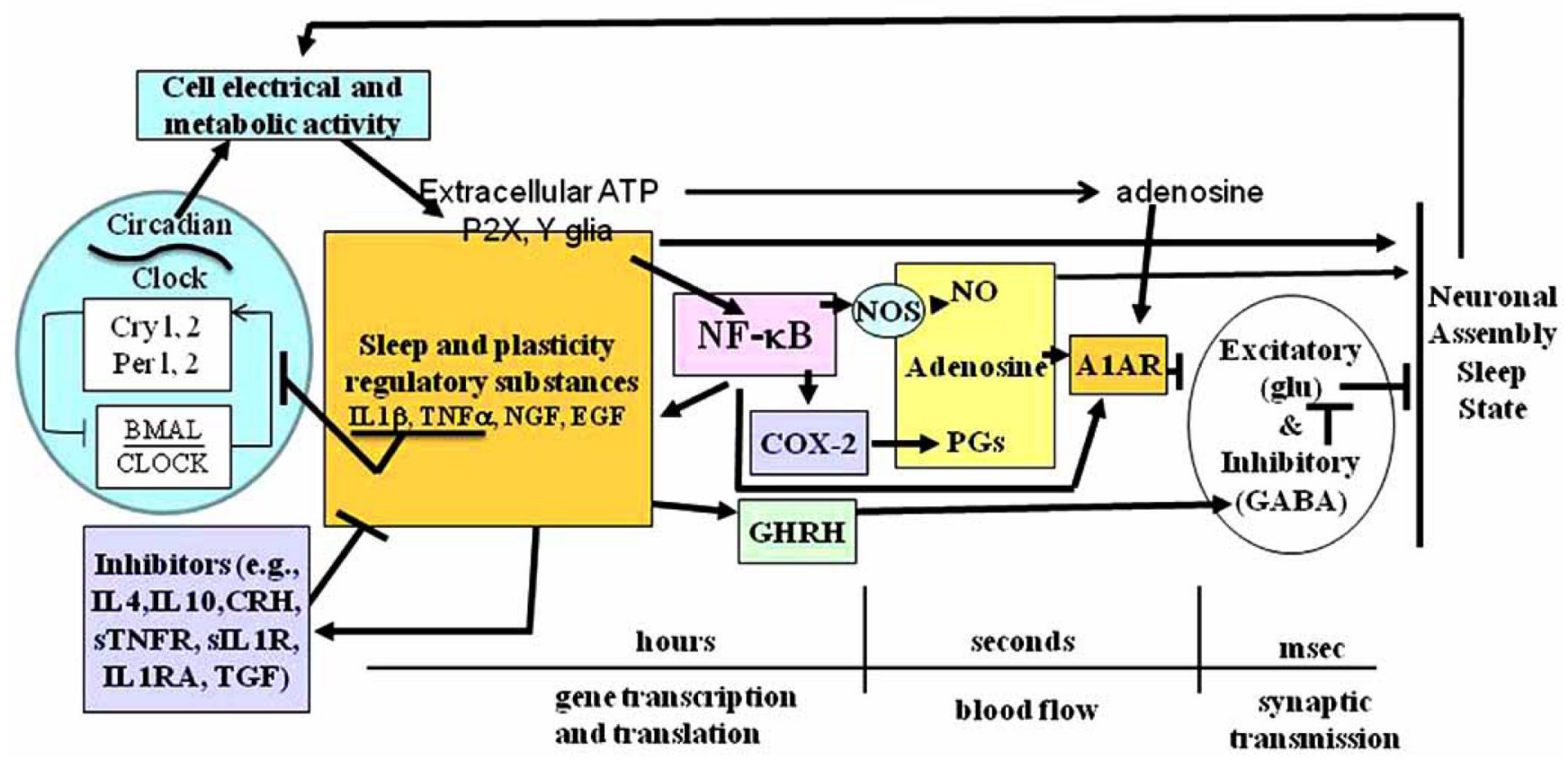

Fig. (2).

Cytokines such as IL1, TNF, nerve growth factor (NGF), EGF, interleukin 4 (IL4), interleukin 10 (IL10), and associated soluble and membrane-bound receptors all form part of the sleep biochemical regulatory network. Cell activity affects levels of these substances. Within brain for example, ATP, co-released during neurotransmission, induces the release of the gliotransmitters IL1 and TNF from glia. These substances induce their own production and interact with multiple other substances via NFkB activation. These effects are associated with gene transcription and translation and take several hours. Downstream events include wellknown metabolic substances and regulators of the microcirculation such as NO, adenosine and prostaglandins. Neurotransmission, acting on an even faster time scale, is altered by substances such as IL1 via actions on the production of receptors that alter postsynaptic neuron sensitivity such as AMPA and adenosine A1 receptors (A1AR). State oscillations within local networks occur as a result of this ultra-complex biochemical regulatory scheme $[2,3,56]$.

Abbreviations:P2, purine type 2 receptors; $\mathrm{NFkB}$, nuclear factor kappa B; NOS, nitric oxide synthase; NGF, nerve growth factor; EGF, epidermal growth factor; GHRH, growth hormone releasing hormone; $\mathrm{CRH}$, corticotrophin releasing hormone; IL1RA, IL1 receptor antagonist; sIL1R, soluble IL1 receptor; sTNFR, soluble TNF receptor; PGs, prostaglandins; COX, cyclooxygenase; glu, glutamic acid; GABA, gamma amino butyric acid; $\mathrm{CRH}$, corticotrophin releasing hormone; sTNFR, soluble TNF receptor;, sIL1R, soluble IL1 receptor; TGF, transforming growth factor beta; cry, cryptochrome; per, period. 


\section{TNF}

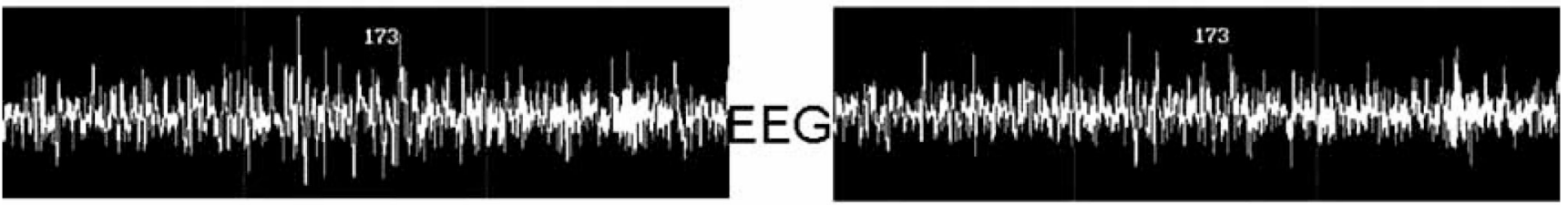

Cannula/EEG Electrodes

Saline

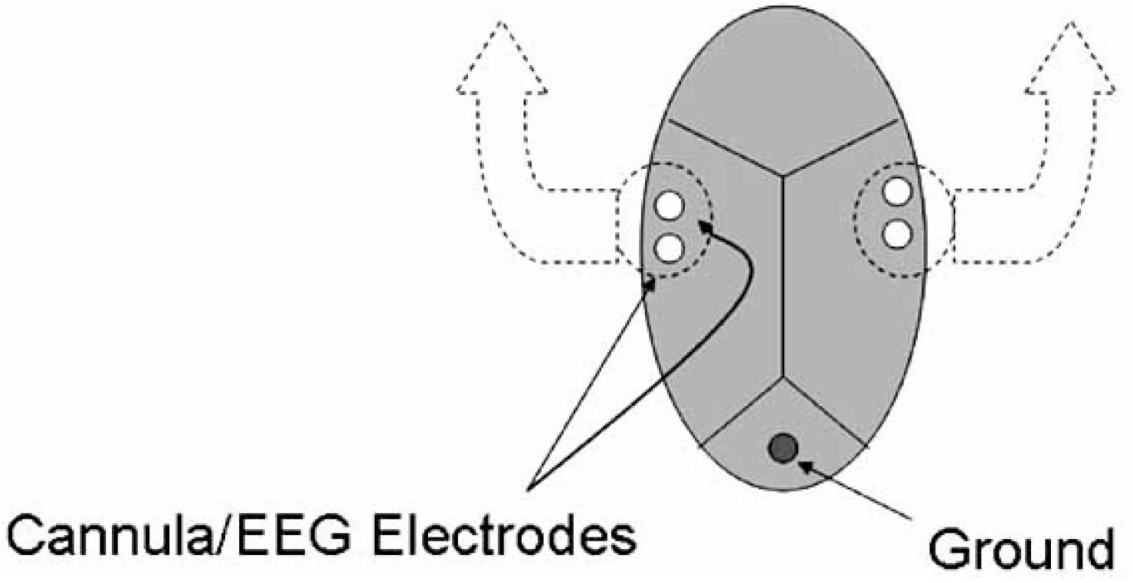

Fig. (3).

Application of tumor necrosis factor alpha (TNF) unilaterally (left) to the somatosensory cortex enhances EEG delta power on the ipsilateral side during NREMS. Such responses occur during NREMS but not during REMS or waking (modified from 86]. 


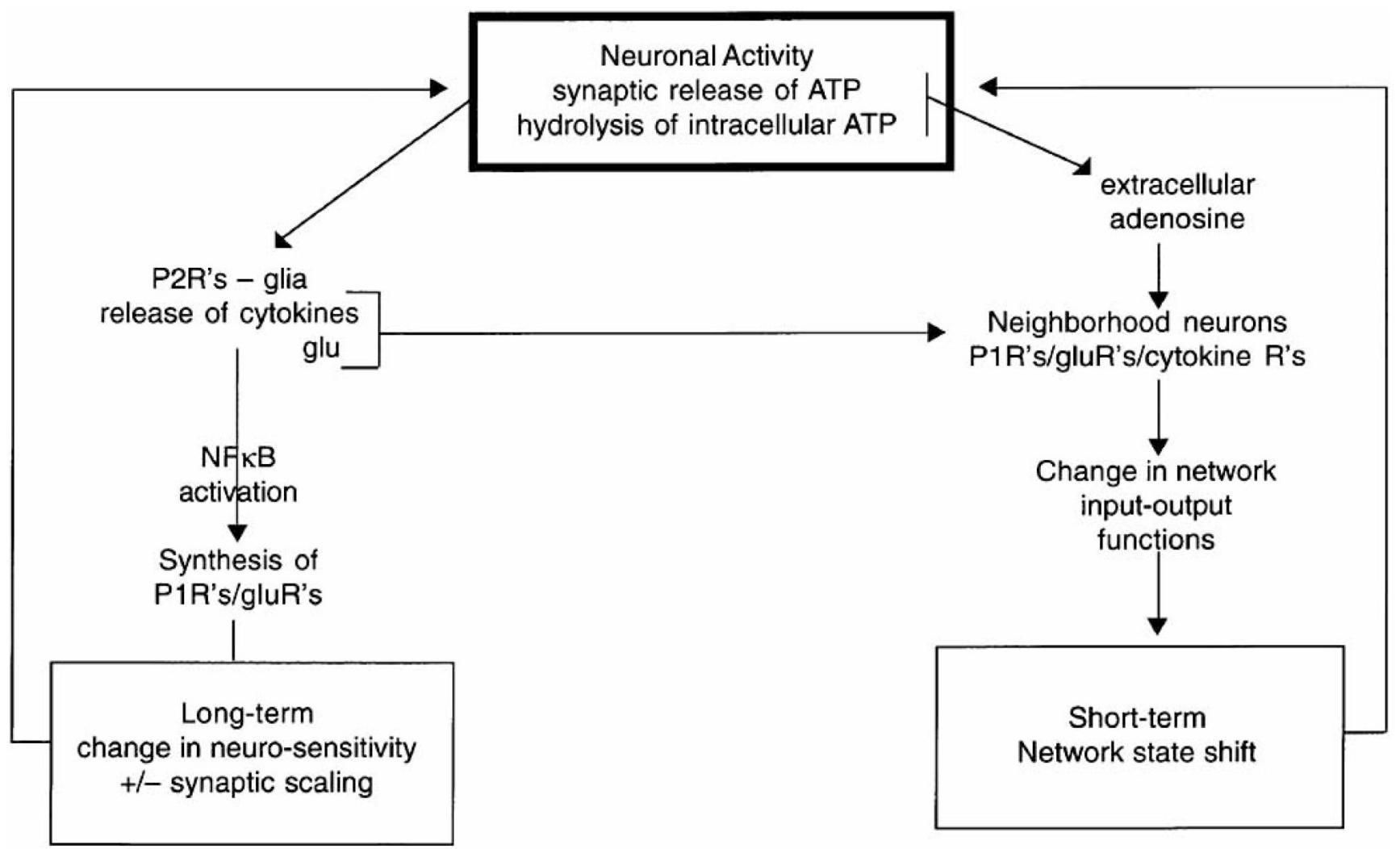

Fig. (4).

Neuronal activity is linked via ATP released during neurotransmission to both long-term and short-term mechanisms involved in neuronal assembly state and in events involved in synaptic scaling. 


\section{Cytokines alter Sleep}

Table 1

\begin{tabular}{|c|c|}
\hline Cytokine/Growth Factor ${ }^{1}$ & Effect on NREMS ${ }^{2}$ \\
\hline Interleukin-1 alpha & $\uparrow$ \\
\hline Interleukin-2 & $\uparrow$ \\
\hline Interleukin-6 & $\uparrow \rightarrow \downarrow$ \\
\hline Interleukin-8 & $\uparrow$ \\
\hline Interleukin-15 & $\uparrow$ \\
\hline Interleukin-18 & $\uparrow$ \\
\hline Epidermal growth factor & $\uparrow$ \\
\hline Acidic fibroblast growth factor & $\uparrow$ \\
\hline Erythropoietin & $\uparrow$ \\
\hline Nerve growth factor & $\uparrow$ \\
\hline Brain derived neurotrophic factor & $\uparrow$ \\
\hline $\begin{array}{l}\text { Glia-derived neurotrophic factor } \\
\text { Neurotrophins } 3 \text { and } 4\end{array}$ & $\begin{array}{l}\uparrow \\
\uparrow\end{array}$ \\
\hline Interferon alpha & $\uparrow \rightarrow \downarrow$ \\
\hline Interferon gamma & $\uparrow$ \\
\hline Tumor necrosis factor beta & $\uparrow$ \\
\hline Granulocyte-macrophage colony-stimulating factor & $\uparrow$ \\
\hline Interleukin-1 receptor antagonist & $\downarrow$ \\
\hline Interleukin-4 & $\downarrow$ \\
\hline Interleukin-10 & $\downarrow$ \\
\hline Interleukin-13 & $\downarrow$ \\
\hline Transforming growth factor beta & $\downarrow$ \\
\hline Granulocyte colony-stimulating factor & $\downarrow$ \\
\hline Insulin-like growth factor & $\begin{array}{c}\text { Small dose: } \downarrow \text {; } \\
\text { high dose: } \uparrow\end{array}$ \\
\hline Soluble TNF receptor & $\downarrow$ \\
\hline Soluble IL1 receptor & $\downarrow$ \\
\hline
\end{tabular}

${ }^{1}$ See Reference 2 for citations.

2 个increase; $\downarrow$ decrease; $\rightarrow$ no change. 